\title{
ESWL 術後結石再発症例の検討
}

\begin{tabular}{lrrrr}
\multicolumn{6}{c}{ 三樹会病院 (院長 : 丹田 } & 均) \\
加藤 & 修爾 氏家 & 徹 & 毛利 & 和富 \\
中嶋 久雄 & 大西 & 茂樹 & 丹田 & 均
\end{tabular}

\section{CLINICAL STUDY ON RECURRENCE OF URINARY TRACT LITHIASIS OF ESWL}

\author{
Shuji Kato, Toru Ujiie, Kazutomi Mori, Hisao Nakajima, Shigeki Ohnishi and Hitoshi Tanda \\ Sanjukai Hospital \\ (Director: H. Tanda)
}

During the 4 year peirod from September 1, 1984 through August 31, 1988, a total of 1,866 patients with calui of the urinary tract (125 patients had bilateral calculi) were subjected to extracorporeal shock wave lithotripsy (ESWL) with a DORNIER HM3 ESWL apparatus. Follow-up was performed factor 1,056 cases 3 or more months after complete elimination of the calculi, and data were obtained for 343 of them. Lithiasis was found to have recurred after ESWL in 30 cases, with a recurrence rate of $11.1 \%$.

Recurrence was seen in $16.9 \%$ of cases with multiple calculi and $6.5 \%$ of cases with a single calculus. The difference wa statistically significant. Surgical removed of calculi or spotaneous discharge of calculi had been experienced in $50.0 \%$ of the reccurent cases and $27.8 \%$ of the non recurrent cases. The difference was also statistically significant. Stone size, stone location and urinary tract infection were unrelated to the recurrence.

\begin{abstract}
要旨：1984年 9 月 1 日より1988年 8 月 31 日までの満 4 年間に, 1,866 例（両側125例）の尿路結石症例を Dornier $\mathrm{HM}_{3}$ を用いて治療した。破碎片の完全排石より 3 力月以上招経過した 1,056 例のうち 343 例が当 院外来で経過観察可能であった。 その結果，343例中 30 例（再発率 $8.7 \%$ ) に新たな結石の再発を認めた。

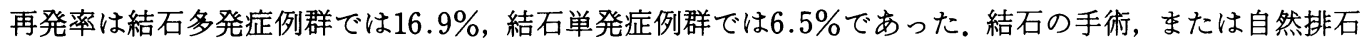
の既往を有する症例は, 再発症例群では $50.0 \%$, 非再発症例群では $27.8 \%$ あった。この差も統計学上, 有意であった。結石の大きさ, 結石の存在部位, 術前の尿路感染症の有無は結石の再発とは無関係であっ た.
\end{abstract}

\section{I. 緒 言}

1980年 2 月に Extracorporeal Shock Wave Lithotripsy (以下 ESWL) が世界で初めて臨床応用されて から 9 年余が経過した。しかし世界的規模で施行され るようになってからは，まだ 4 年余にすぎない。従っ て同法施行後の結石再発率に関する報告は少ない，当 院では1984年 9 月 1 日に ESWLを開始し，1988年 8 月末日で満 4 年を経過した。 今回我々はこの間完全排 石後に再発したと考えられる結石再発症例を臨床的に 検討したので報告する。

\section{II. 対象及び方法}

1984年 9 月 1 日から 1988 年 8 月 31 日までの満 4 年間 に1866例の尿路結石症例を Dornier $\mathrm{HM}_{3}$ で治療した。 術後経過観察が可能であった 1,279 例のらち, 3 カ月以
上の follow-up で完全排石した症例は1,056例, 82.6\% であった。このうち完全排石後, 更に 3 カ月以上経過 した症例を対象に結石再発を検討した。完全排石後 3 カ月以内に再度出現した結石陰影は, 前回の撮影条件 等によりたまたま描出されなかった症例が多いと考え 再発例からは除外した。再発の検討を当院外来受診に よる KUB, IVP 等により行った.

\section{III. 結 果}

343例を追跡調査し 30 例（8.7\%）に結石の再発を認 めた. 経過観察期間は最短 4 力月, 最長 40 力月, 平均 12.6力月であった。 また, 再発までの期間は最短 4 カ 月, 最長 36 力月, 平均 10.1 月であった。再発症例を 下記の項目に従い検討した。

1）性別，年齢別の再発率（Table 1) 
Table 1 Recurrence Rate as Function of Sex and Age

\begin{tabular}{l|c|r|r|r}
\hline & \multicolumn{4}{|c}{ Age (years) } \\
\hline Sex & $0-20$ & $21-60$ & $61 \leqq$ & Total \\
\hline Male & $1 / 6(16.7 \%)$ & $16 / 198(8.1 \%)$ & $5 / 36(13.9 \%)$ & $22 / 240(9.2 \%)$ \\
Female & $1 / 5(20.0 \%)$ & $5 / 85(5.9 \%)$ & $2 / 13(15.4 \%)$ & $8 / 103(7.8 \%)$ \\
\hline Total & $2 / 11(18.2 \%)$ & $21 / 283(7.4 \%)$ & $7 / 49(14.3 \%)$ & $30 / 343(8.7 \%)$ \\
\hline
\end{tabular}

Table 2 Size of Calculus and Recurrence Rate

\begin{tabular}{c|c|r|r|c}
\hline & $\begin{array}{l}\text { No. of } \\
\text { non-recurrent } \\
\text { cases }\end{array}$ & $\begin{array}{l}\text { No. of } \\
\text { recurrent } \\
\text { cases }\end{array}$ & Total & $\begin{array}{l}\text { Recurrence } \\
\text { rate (\%) }\end{array}$ \\
\hline $0-10 \mathrm{~mm}$ & 126 & 12 & 138 & $8.7 \%$ \\
\hline $11-20$ & 134 & 11 & 145 & $7.6 \%$ \\
\hline $21-30$ & 31 & 2 & 33 & $6.1 \%$ \\
\hline $31-$ & 8 & 4 & 12 & $33.3 \%$ \\
\hline Staghorn calculus & 14 & 1 & 15 & $6.7 \%$ \\
\hline Total & 313 & 30 & 343 & $8.7 \%$ \\
\hline
\end{tabular}

Table 3 Recurrence Rate as Function of Site of Initial Calculus

\begin{tabular}{l|c|r|r|r}
\hline & $\begin{array}{l}\text { No. of } \\
\text { non-recurrent } \\
\text { cases }\end{array}$ & $\begin{array}{l}\text { No. of } \\
\text { recurrent } \\
\text { cases }\end{array}$ & Total & $\begin{array}{l}\text { Recurrence } \\
\text { rate (\%) }\end{array}$ \\
\hline Kidney & 133 & 19 & 152 & $12.5 \%$ \\
\hline Staghorn & 14 & 1 & 15 & $6.7 \%$ \\
\hline Kidney and ureter & 24 & 4 & 28 & $14.3 \%$ \\
\hline Ureter & 124 & 6 & 130 & $4.6 \%$ \\
\hline Lower ureter & 18 & 0 & 18 & $0.0 \%$ \\
\hline \multicolumn{1}{c|}{ Total } & 313 & 30 & 343 & $8.7 \%$ \\
\hline
\end{tabular}

男 $9.2 \%$ ，女 $7.8 \%$ で性差は無い。年齢別に見ても再 発率に有意差は無かった。

2) 結石の大きさと再発率 (Table 2)

結石の長径が $3 \mathrm{~cm}$ を越えると，33.3\%と一見再発率 が高くなる様だが, 删瑚状結石では $6.7 \%$ と低く, 両者 の間には相関は無いと考员たほうがよい様であった。

3）治療時の結石存在部位と再発率（Table 3)

腎尿管に同時に結石が存在した症例の再発率が $14.3 \%$ と高い。これは結石の多発と言う意味で再発率 が高いものと思われた。

4) 結石の数と再発率 (Table 4)

結石の存在部位別に見ても，いずれも多発結石症例 の再発率が高く, Total で単発例の再発率 $6.5 \%$, 多発
Table 4 Recurrence Rate as Function of Single/ Multiple Calculi

\begin{tabular}{l|c|c}
\hline & Single cases & Multiple cases \\
\hline Kidney & $10 / 97(10.3 \%)$ & $9 / 46(19.6 \%)$ \\
\hline Staghorn & $1 / 15(6.7 \%)$ & \\
\hline Kidney and ureter & & $4 / 24(16.7 \%)$ \\
\hline Ureter & $5 / 118(4.2 \%)$ & $1 / 11(9.1 \%)$ \\
\hline Lower ureter & $0 / 16(0.0 \%)$ & $0 / 2(0.0 \%)$ \\
\hline \multicolumn{1}{c|}{ Total } & $16 / 246(6.5 \%)$ & $14 / 83(16.9 \%)$ \\
\hline
\end{tabular}

例の再発率 $16.9 \%$ であった。この結果は $\chi^{2}$ 検定で統計 学的に有意差を認めた。

5）結石成分と再発率（Table 5)

Cystine の再発率が他の成分に比べて高い様である が, 症例数の小ないものもあり, 断定出来ない. Cystine の再発例はいずれも再発防止剤の服用中であった。

6）術前の尿路感染症の有無と再発率（Table 6)

UTI の複雑性尿路感染症の基準に則り，術前尿中白 血球 5 個以上を尿路感染存在例とした。非再発例群の 尿路感染症合併率は $23.3 \%$ 再発症例群のそれは $10.0 \%$ であり，両者間に有意差はなかった。をた，尿細菌培 養により $10^{4} / \mathrm{ml}$ 以上の細菌尿を認めた症例は非再発 症例群で $3.3 \%$, 再発症例群で $6.7 \%$ あっただ, 両者 間に有意差は無かった。従って尿路感染の有無と再発 率との間に相関はないと思われる。

7）結石の既往と再発率（Table 7)

ESWL 前の結石の既往と再発率との関係を見た。手 術および自然排石のいずれかの既往を有する症例は， 非再発群では $27.8 \%$ であった。一方再発群の既往あり は $50.0 \%$ と高く，この結果は， $x^{2}$ 検定で有意差を認め た.

8) 泌尿器科合併症と再発 (Table 8)

尿管狭窄，重複腎孟尿管，馬蹄鉄腎，尿流変更術後 状態と結石再発との関係を見た。上記疾患の合併率は 非再発群で $6.7 \%$ 再発群で $6.7 \%$ と同率であった。 
Table 5 Constituents of calculus and Recurrence Rate

\begin{tabular}{l|c|c|c|c}
\hline Constituent of calculus & $\begin{array}{l}\text { No. of } \\
\text { non-recurrent } \\
\text { cases }\end{array}$ & $\begin{array}{l}\text { No. of } \\
\text { recurrent } \\
\text { cases }\end{array}$ & Total & $\begin{array}{l}\text { Recurrence } \\
\text { rate (\%) }\end{array}$ \\
\hline Pure calcium oxalate & 50 & 6 & 56 & $10.7 \%$ \\
\hline $\begin{array}{l}\text { Mixed calcium oxalate } \\
\text { and phosphate }\end{array}$ & 163 & 13 & 176 & $7.4 \%$ \\
\hline Pure calcium phosphate & 20 & 4 & 24 & $16.7 \%$ \\
\hline $\begin{array}{l}\text { Magnesium ammonium } \\
\text { phosphate (struvite) }\end{array}$ & 4 & 0 & 4 & $0.0 \%$ \\
\hline Uric acid & 20 & 3 & 23 & $13.0 \%$ \\
\hline Cystine & 1 & 1 & 5 & $20.0 \%$ \\
\hline Artifacts and others & & 0 & 1 & $0.0 \%$ \\
\hline
\end{tabular}

Table 6 Pre-ESWL Urinary Tract Infection and Recurrence Rate

\begin{tabular}{l|c|c|c|c}
\hline & $\begin{array}{c}\text { Pyuria } \\
(\text { WBC } 5 \leqq / \mathrm{HPF}) \\
(+)\end{array}$ & $\begin{array}{c}\text { Pyuria } \\
(-)\end{array}$ & $\begin{array}{c}\text { Bacteriuria } \\
\left(10^{4} \leqq\right. \\
(+)\end{array}$ & $\begin{array}{c}\text { Bacteriuria } \\
(-)\end{array}$ \\
\hline Non-recurrent cases & $7 / 30(23.3 \%)$ & $23 / 30(76.7 \%)$ & $1 / 30(3.3 \%)$ & $29 / 30(96.7 \%)$ \\
\hline Recurrent cases & $3 / 30(10.0 \%)$ & $27 / 30(90.0 \%)$ & $2 / 30(6.7 \%)$ & $28 / 30(93.3 \%)$ \\
\hline
\end{tabular}

Table 7 Relationship between Past History of

Calculi before ESWL and Recurrence Rate

\begin{tabular}{c|c|c}
\hline & $\begin{array}{l}\text { Non-recurrent } \\
\text { cases } \\
(313 \text { cases })\end{array}$ & $\begin{array}{l}\text { Recurrent } \\
\text { cases } \\
(30 \text { cases })\end{array}$ \\
\hline Surgical removal & $50(16.0 \%)$ & $12(40.0 \%)$ \\
\hline Spontaneous discharge & $37(11.8 \%)$ & $3(10.0 \%)$ \\
\hline Total & $87 / 313(27.8 \%)$ & $15 / 30(50.0 \%)$ \\
\hline
\end{tabular}

Table 8 Urological Complications and Recurrence Rate

\begin{tabular}{l|c|c}
\hline & $\begin{array}{c}\text { Non-recurrent cases } \\
(313 \text { cases })\end{array}$ & $\begin{array}{c}\text { Recurrent cases } \\
(30 \text { cases })\end{array}$ \\
\hline Ureteral stenosis & $16(5.1 \%)$ & $2(6.7 \%)$ \\
\hline Ureteral duplication & $3(1.0 \%)$ & $0(0.0 \%)$ \\
\hline Horseshoe kidney & $1(0.3 \%)$ & $0(0.0 \%)$ \\
\hline Urinary diversion & $1(0.3 \%)$ & $0(0.0 \%)$ \\
\hline \multicolumn{1}{c}{ Subtotal } & $21(6.7 \%)$ & $2(6.7 \%)$ \\
\hline
\end{tabular}

\section{IV. 考 察}

尿路結石症の各種治療法の評価において治療後の残 石率と共に治療後の結石再発率も大きな要因となる。 結石再発に関して文献的に見てみると，公文ら ${ }^{1}$ は，
尿路結石症 1,069 例を検討し, そのらち結石の既往を有 するものは，269例，25.2\%であったと報告している. これら269例は自然排石後及び手術療法後の再発と考 えられ，ESWL 及び PNL 導入前の全体的な意味での 尿路結石の再発率とも考兄られる。

一方, open surgery 後の再発を見てみると, 伊藤ら は，腎孟切石術44例中 9 例（20\%）に平均観察期間 20 カ月で再発を認め，また，腎切石術 9 例中 2 例(20\%) に平均観察期間23力月で再発をみたとしている.

堀田ら は $^{3}$, 多発腎結石症例31例を $3 \sim 6$ 年にわた り経過観察し, 腎孟切石術及び腎切石術症例 22 例中 13 例, $59 \%$ に再発を認めたが 9 例の腎部分切除術症例で, 再発は無かったと報告している。

しかし，腎部分切除術に関して Timoney ら ${ }^{4)}$ の25例 中 $33 \%$ に再発を認めたといら報告もあり再発率は一定 しない。

PNL 後の再発率に関して, Marberger ら5) は82例中 2 例 $(2.4 \%)$ に平均観察期間 22 力 月で再発を認めたと 報告している。 また, Schulze ら ${ }^{8)}$ は90例の珊瑚状結石 症例に対し, PNLと ESWLの併用療法を行い, 平均 観察期間 2 年で再発率は $15.6 \%$ であったと報告してい る.

ESWL 後の再発率の報告では, Newman ら¹は653 
例の 1 年間に渡る follow up で $8.5 \%$ に結石の再発を

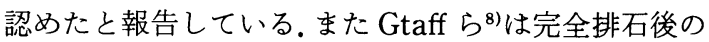
353人の follow-up を行い, 平均 19.1 月の観察では $6.2 \%$ 結石の再発を認めたと報告している.これらの 再発率は，我々の報告した再発率 $8.7 \%$ と注涪同率で あった。

しかし我々の結果を含めて期間がまだ十分ではな く, 観察期間が今後延長するのに従って再発率のかな りの変動があるかも知れない，尿路結石症に対する各 種手術療法後の再発率を調べて感じた事は, open surgery群においては，その症例数が少なく，また，PNL 及び ESWLでは症例数は十分でも，その経過期間が 短いといら事であった。従って, 再発率の問題から, ESWL またはPNLの優位性を論ずるのは今だその 時期では無いと考える。また，今回の我々の再発症例 の検討において統計学的に有意差を認めた再発要因 は, (1)多発結石症例，(2) ESWL 前の結石既往を持った 症例の二点であった。この事実は, ESWL 後の結石再 発に関しては一般的な再発要因と同じく，何かまだ知 られていない個体の結石再発要因が存在するといら事 のみであった。

\section{V. 結 語}

ESWL 後完全排石した症例343例を追跡調査し30例 （8.7\%）に結石の再発を認めた。ささらに再発症例を検 討し下記の結果を得た。

(1) 結石多発症例群及び結石の既往のある症例群に 統計学的に有意に結石の再発傾向を認めた。

(2) 結石の存在部位, 結石の大きさ, 術前の尿路感染 の有無は結石再発とは無関係であった。

本文の趣旨は第76会日本泌尿器科総会及び第 6 回 International Symposium on Urolithasis に拈いて報告した。

\section{文献}

1）公文裕己, 朝日俊彦, 津川昌也, 沖宇正明, 富田和 富, 大森弘之：尿路結石症に関する臨床的考察. 岡 山学会雑誌, 96, 1019-1027, 1984.

2）伊藤春夫, 村上光右, 宮内大成, 内藤 化, 森偉久 夫, 山口邦夫, 白井利夫, 甘粕 誠, 島崎 淳：腎 手術に拈けるコアグルム使用の仮性再発及び真性 再発に対する効果. 日泌尿会誌, 75, 1523-1527, 1984.

3）増田富士男, 沖田浄治郎, 望月 篤, 近藤 泉, 黒 田 淳, 遠藤勝久: 多発性下腎杯結石の腎部分切 除術による治療。日泌尿会誌，78，1914-1916， 1987.

4) Timoney, A.G., Payne, S.R., Walm Sley, B.H., Vinnicombe, J. and Abercrombie, G.F.: Partial nephrectomy : an option in calculus disease? Brit. J. Urol., 62, 511-514, 1988.

5) Marberger, M., Stackl, W., Hruby, W. and Kroiss, A.: Late sequelae of ultrasonic Lithotripsy of renal calculi. J. Urol., 133, 170-173, 1985.

6) Schulze, H., Hertle, L., Kutta, A., Graff, J. and Senge, T.: Critical evaluation of treatment of Staghorn calculi by percutaneous nephrolithotomy and extracorporeal shock wave Lithotripsy. J. Urol., 141, 822-825, 1989.

7) Newman, D.M., Lingeman, J.E. and Scott, J.W. : Long term follow-up of 2,617 Extra corporeal Shock Wave Lithotripsy patients. Abstracts of the fifth world congress on endourology and ESWL, 1987.

8) Graff, J., Diederichs, W. and Schulze, H.: Long term follow-up in 1,003 Extraco rporeal Shock Wave Lithotripsy patients. J.U, 479-483, 1988.

（1989年10月30日受理，特別掲載） 